Maciej Żenkiewicz*

Tadeusz Wasilewski***

\title{
THE GALLEON 'SAN JOSÉ'. ALMOST FOUR DECADES OF LEGAL STRUGGLES ON THE NATIONAL AND INTERNATIONAL PLANE
}

\begin{abstract}
The article presents the history and current disputes surrounding the Galleon San Jose. As an on-going case since 1980s, the dispute involves various actors on national, as well as international level. The article discusses this issue focusing on four relevant elements: international and national law, politics and diplomacy. Legal obligations under international law which may be applicable to San Jose galleon are presented, with comments regarding its applicability to Colombia. Subsequently, Colombian relevant national legislature and judicial decisions are discussed, to establish how the Galleon with its treasures may be classified under Colombian civil law. In the last part two elements are presented, namely: politics and diplomacy. This part presents in particular an attitude and actions regarding the case after announced discovery of the shipwreck of the Galleon in 2015.
\end{abstract}

\section{Keywords}

Galleon San Jose - Colombia - Underwater heritage - treasure - UNCLOS - UNESCO

* Research Professor, Department of Economic Law, Universidad de Externado de Colombia. Visiting Professor at Faculty of Social Sciences of the Antonio de Nebrija University; ORCID 0000-0001-9325-5579; e-mail: maciej.zenkiewicz@gmail.com.

** Professor, Chair of International Law, Faculty of Law and Administration, Nicolaus Copernicus University in Torun. 


\section{INTRODUCTION}

On 8 June 1708, during the naval battle of Barú, the Spanish galleon San José, with unimaginable wealth, precious stones, and loads of gold and silver as its cargo, was lost in the deeps of the blue sea, leaving only 11 of its crew on the surface ${ }^{1}$. The galleon San José was carrying the treasure, which was collected during 6 years in the Spanish colonies in the New World. Philip the Fifth, King of Spain, was waiting and depending on this income, as his main source to finance his War of the Spanish Succession. Therefore, the British cannons on that date, not only sank the galleon, but, more importantly, also sank the hope and chances of Spanish king of winning his war'.

Even if that fierce battle was over, the afterlife of the San José galleon was only about to start. Lost, but not forgotten, the wreck of this ship was hidden in the deep blue sea for centuries. The galleon San José with its precious cargo was inspiring the minds of adventurer and treasure hunters ${ }^{3}$.

Since the 1980s, when the galleon was supposedly found, and more recently since 2015, when the discovery of the galleon San José was officially announced by the President of Colombia ${ }^{4}$, the galleon is once again in the middle of a battle, but this time not with guns and powder, but with diplomatic, archaeological, and legal arguments before various national and international courts, and between various actors.

Legal battles for rights to underwater wrecks and treasures involve various parties, usually at least a private investor v. the State, with multiple transmutations, most commonly with the interests of other

${ }^{1}$ See: C. Rahn, P. B. Hattendorf, T. R. Beall, The sinking of the Galleon San José on 8 June 1708: An exercise in historical detective work, The Mariner's mirror, num. 94, issue 2, March 2013, pp. 176-187. DOI: 10.1080/00253359.2008.10657053.

2 See: J. Falkner, War of Spanish Succession 1701-1714, Pen \& Sword Books Ltd. 2015.

${ }^{3}$ Rahn et al, supra note 1 at p. 179.

${ }^{4}$ See: El Heraldo, Así comunicó el presidente Santos el hallazgo del galeón San José, 5 December 2015, accesible at: https:/ / www.elheraldo.co/nacional/asi-comunico-santosel-hallazgo-del-galeon-san-jose-232099 [last accessed 1.11.2019] 
States engaged ${ }^{5}$. There is no difference in the case of the San José galleon. Today, the status and future of the San José galleon is subject to dispute between various actors. The first front of the battle, however, was between Colombia and a private company, although there are more actors interested. The following states may be mentioned as having legal interests or as being involved in that dispute: Colombia, Spain, the United States of America ${ }^{6}$, and even Bolivia ${ }^{7}$.

What is more, another strong debate and confrontation exists within Colombia - between the Government and its plan on how to resolve that dispute and the academics, organizations, and society in general. But this governmental attitude has changed recently, with the change at the presidential palace in 2018.

The history of Colombian national law and international obligations related to underwater heritage and sunken treasure is intertwined with the history of the San José galleon. This article has as its objective to briefly present the legal problems surrounding the San José galleon, however with the reservation that this is still an on-going dispute, and new solutions and new development may occur at any moment. For that reason, the article will not contain an in-depth analysis of all the legal issues, as many

${ }^{5}$ For example, the well discussed case of Galleon Nuestra Señora de Mercedes (also referred to as the case of 'Black Swan') See: M. R. Nelson, Finders, Weepers-Losers, Keepers? Florida Court says U.S. Company Must Return Recovered Treasure to Kingdom of Spain, 16 Law \& Bus. Rev. Am. 2010, p. 587. D. Curfman, Thar be Treasure Here: Rights to Ancient Shipwrecks in International Waters - A New Policy Regime, Wash. U. L. Rev., num. 86 2008-2009. p. 181; J. Tsai, Curse of the Black Swan: How the Law of Salvage Perpetuates Indeterminate Ownership of Shipwrecks, 42 Int'1 Law 2008, p. 211.

${ }^{6}$ On 7 of December 2010, SSA filed a suit against Colombia in the United States, which was dismissed owing to procedural issues. See case Sea Search Armada v. Republic of Colombia, Civil Action No. 10-2083 (JEB), UNITED STATES DISTRICT COURT FOR THE DISTRICT OF COLUMBIA, Memorandum opinion (accessible at: https:/ / www.govinfo. gov/content/pkg/USCOURTS-dcd-1_10-cv-02083/pdf/USCOURTS-dcd-1_10-cv-02083-0. pdf) [last accessed: 1.11.2019].

${ }^{7}$ Intervention of Comunidad Qara Qara (Bolivia) - indigenous people who occupy the territory near the POTOSI mines. They argue that the cargo of Galleon San José come from the mines from their territory, and therefore they have historical rights to the treasure. See Leonardo Botero Fernández, El reclamo indígena por el galeón San José, El Espectador, 2 August 2018, https:/ / www.elespectador.com/noticias/nacional/el-reclamo-indigenapor-el-galeon-san-jose-articulo-803934. [last accessed 1.11.2019]. 
relevant facts have still not been established. But the dispute regarding the galleon, which has been going on since the 1980s, continues to be relevant today, which justifies the authors' effort to at least conclude where they are standing right now, as at the date of 1 November 2019.

The article presents four relevant elements for the current dispute: international law, national law, politics, and diplomacy. First, legal obligations under international law which may be applicable to the San José galleon, with comments regarding its applicability to Colombia. Second, the Colombian relevant national legislature and judicial decisions. Third, the last two elements together, politics and diplomacy, and attitude and actions regarding the case after its announced discovery in 2015.

\section{INTERNATIONAL LAW}

The protection of underwater cultural heritage is obviously within the interest of international law. However, the landscape of international obligations is not perfectly clear, as nowadays the regime which refers to underwater shipwrecks is regulated by the both international and national law of each State. Also there is no one universal regime, as the world today is covered to a larger or lesser extent by various treaties with different, sometimes opposing sets of rules, with different legal force and with different geographical coverage - according to a number of ratifications by states.

The international rules evolve together with the technical capacity to explore the depths of the seas further and further. After the Second World War UNESCO introduced recommendations applicable to underwater wrecks ${ }^{8}$. Later on, in the United Nations Convention on the Law of the

${ }^{8}$ See Recommendation on International Principles Applicable to Archaeological Excavations; Resolution adopted on 5th December 1956 by General Conference of UNESCO at its 9th session held in New Delhi. Available at: http://portal.unesco.org/ en/ev.php-URL_ID=13062\&URL_DO=DO_TOPIC\&URL_SECTION=201.html; see also Recommendation concerning the Preservation of Cultural Property Endangered by Public or Private works, Resolution adopted at 19th November, 1968, by General Conference of UNESCO at its 15th session held in Paris. Available at: http:/ / portal.unesco.org/en/ ev.php-URL_ID=13085\&URL_DO=DO_TOPIC\&URL_SECTION=201.html [last accessed 1.11.2019]. 
Sea adopted on 1982 (UNCLOS) ${ }^{9}$, also various stipulations relevant for underwater wrecks were included.

UNCLOS contains stipulations which may be applicable to sunken ships as archaeological objects. Article 303 of UNCLOS established: first, a legal obligation for all states to protect and cooperate in the protection of underwater treasures/heritage; second, that any extraction which is not authorized by the state should be penalized and; third, that apart from in situ preservation, also the rights of identifiable owners, the law of salvage, or other rules of admiralty, or laws and practices with respect to cultural exchanges, should be respected ${ }^{10}$.

Later on, in 1989, the International Convention on Salvage was adopted. That Convention, which regulates extensively the question of the law of salvage, was prepared by the International Maritime Organization, and came into force on 14 June 1996 and up to today it has been ratified by 72 countries $^{11}$.

Since 1990, more specific acts which refer precisely to underwater heritage or underwater patrimony have been adopted, marking also the growing concern and interest of the international community regarding that problem. In this regard, the work of ICOMOS has to be acknowledged ${ }^{12}$. Its first important contribution was the so-called Lausanne Charter ${ }^{13}$. In that document, joint responsibility for the protection of the archaeological patrimony was established ${ }^{14}$ and also the importance of including policies regarding protection in every level of

${ }^{9}$ Convention on the Law of the Sea adopted on 10 December 1982, available at: https:/ / www.refworld.org/docid/3dd8fd1b4.html [last accessed 1.11.2019].

${ }_{10}$ Ibid. Article 303 Archaeological and historical objects.

${ }_{11}$ International Maritime Organization. Status of treaties. 2019. Available at: http:/ / www.imo.org/en/About/Conventions/StatusOfConventions/Documents/ StatusOfTreaties.pdf. [last accessed 1.11.2019].

${ }^{12}$ ICOMOS is a non-governmental international organisation dedicated to the conservation of the world's monuments and sites.

${ }^{13}$ Charter for the Protection and Management of the Archaeological Heritage (1990) Prepared by the International Committee for the Management of Archaeological Heritage (ICAHM) and/as approved by the 9th General Assembly of ICOMOS in Lausanne in 1990. Available at: http://wp.icahm.icomos.org/wp-content/uploads/2017/01/1990Lausanne-Charter-for-Protection-and-Management-of-Archaeological-Heritage.pdf [last accessed 1.11.2019].

${ }^{14}$ Ibid. Art. 3. 
legislation $^{15}$. That Charter in general promotes the protection of the underwater heritage in situ ${ }^{16}$. The second significant contribution was a legal document the Charter on the Protection and Management of Underwater Cultural Heritage (hereafter: Sofia Charter) ${ }^{17}$, which established as its fundamental principle that: "the preservation of underwater cultural heritage in situ should be considered as the first option"18 $^{\prime 1}$ and commercialization is not a desirable way ${ }^{19}$.

In the year 2001, the next important legal development was accomplished under the auspices of UNESCO. The Convention on the Protection of the Underwater Cultural Heritage ${ }^{20}$, (UNESCO Convention), was adopted during the Conference of the United Nations Educational, Scientific, and Cultural Organization, at its thirty-first session in Paris ${ }^{21}$. In general, the UNESCO Convention introduced rules to protect the underwater heritage with a strong preference for preservation in situ ${ }^{22}$. Also, in its article 4 the relationship to the law of salvage and law of finds was introduced, where it is clearly indicated that: "any activity relating to underwater cultural heritage to which this Convention applies shall not be subject to the law of salvage or law of finds", unless covered by exceptions enumerated in that article ${ }^{23}$.

It is relevant to assess to what extent Colombia is bound by the international obligations mentioned above. As a starting point, it has to

${ }^{15}$ Ibid. Art. 2.

16 Ibid. Art. 3.

17 ICOMOS, CHARTER ON THE PROTECTION AND MANAGEMENT OF UNDERWATER CULTURAL HERITAGE (1996) Ratified by the 11th ICOMOS General Assembly in Sofia, Bulgaria, October 1996. Available: https:/ / www.icomos.org/18thapril/ underwater-eng.pdf [last accessed 1.11.2019].

18 Ibid. Art. 1.

${ }^{19}$ Ibid. Introduction and Article 13.

${ }^{20}$ UNESCO, Resolution adopted on the report of Commission IV at the 20th plenary meeting, on 2 November 2001. Text of the Convention available at: https://unesdoc. unesco.org/ark:/48223/pf0000124687.page=56 [last accessed 1.11.2019].

${ }^{21}$ Meeting was conducted in Paris from 15 October to 3 November 2001.

22 Sofia Charter, at Annex, General Principles, Rule 1, "The protection of underwater cultural heritage through in situ preservation shall be considered as the first option".

${ }^{23}$ Ibid. Art 4. Those exceptions are: (a) is authorized by the competent authorities, and (b) is in full conformity with this Convention, and (c) ensures that any recovery of the underwater cultural heritage achieves its maximum protection. 
be noted that Colombia has not ratified any of the previously mentioned conventions, therefore formally it is not bound by their obligations. However, so as to understand the position of Colombia and its absence in this evolving international legal regime, in this part the Colombian standpoint will be briefly presented, especially regarding the UNESCO Convention (2001).

During the development of international obligations regarding the underwater heritage, Colombia has always been pending and active, as one of the states which has special interest in those regulations. However, owing to the serious concerns and fears of restraining its capacity to regulate freely the legal status of encountered shipwrecks and treasure within its jurisdiction, Colombia was very cautious over assuming any international obligations.

First, Colombia has not ratified UNCLOS, which by today has been ratified by more than 160 states $^{24}$. However, Colombia was not openly against the rules enshrined in UNCLOS, which may be applicable to the current situation. As various commentators present, UNCLOS is nowadays treated as the world constitution on the law, and its principles owing to their worldwide acceptance, may be considered as reflecting the rules of customary international law ${ }^{25}$, and such a view seems to be shared also among Colombian academics ${ }^{26}$. Also they highlighted, especially in the light of the Colombian non ratification of UNESCO Convention, that UNCLOS established a fragile balance between two opposite tendencies ${ }^{27}$. On the one hand, underwater ships should be treated as heritage of the mankind and cultural patrimony and, therefore, should be preserved

${ }^{24}$ Oceans and law of the Sea United Nations, Chronological lists of ratifications of, accessions and successions to the Convention and the related Agreements, 2019, available at: https://www.un.org/Depts/los/reference_files/chronological_lists_of_ratifications. htm. [last accessed 1.11.2019].

25 See G. Mangone, W. Burke, Introduction. Proceedings of the Annual Meeting, American Society of International Law, 1987, pp. 75-84. Retrieved from www.jstor.org/ stable/25658351. Cf. P. Tzeng, Jurisdiction and applicable law under UNCLOS, Yale Law Journal, vol. 126, issue 1, 2016, pp. 242-260.

26 A. J. Rengifo Lozano, Las objeciones de Colombia a la Convención Internacional de la UNESCO sobre Protección del Patrimonio Cultural Subacuático, Pensamiento Jurídico, núm. 25, 2009, p. 123.

27 Ibid., p. 124. 
at the place (in situ) and not extracted. On the other hand, Convention allows for the extraction and commercialization of some of the treasures. Worth noticing is that those rules are applicable to archaeological and historical objects, which were found not within, but beyond the limits of national jurisdiction ${ }^{28}$.

Colombia has not ratified the UNESCO Convention, which was finally approved in Paris on 2 November 2001, after almost 3 years of extensive discussion and diplomatic work. Colombia had been actively participating in the works on the Convention, although, at the end of the road, she refused to ratify the UNESCO Convention. During October 2001 a profound dispute regarding the ratification was conducted in the Colombian Congress of the Republic, which led to a radical change in the Colombian position ${ }^{29}$. The reasoning for such a decision is relevant to understanding the current dispute surrounding the San José galleon. Therefore, the concerns of Colombia regarding the UNESCO Convention 2001 should be mentioned ${ }^{30}$.

In general, Colombia's position seems to be obviously against strengthening the rights of the flag state. For its geographical position and having access to both Oceans and more than 3200 kilometers of coastline $^{31}$, Colombia is against any proposal to weaken the rights of

${ }^{28}$ Ibid. Art 149 in connection with Article 1, point 1, (1) (definition of Area) Article 1.1.(1): "Area" means the seabed and ocean floor and subsoil thereof, beyond the limits of national jurisdiction; Article 149 Archaeological and historical objects. All objects of an archaeological and historical nature found in the Area shall be preserved or disposed of for the benefit of mankind as a whole, particular regard being paid to the preferential rights of the State or country of origin, or the State of cultural origin, or the State of historical and archaeological origin.

29 Regarding the debate in the Colombian Congress, see official document: Acta de Comisión 10 del 23 de Octubre de 2001 Senado - GACETA DEL CONGRESO: 16417/05/2002. http:/ / svrpubindc.imprenta.gov.co/senado/index2.xhtml?ent=Senado\&fec=17-52002\&num $=164 \&$ consec $=4505$ [llast accessed 1 11. 2019].

${ }^{30}$ Colombian objections regarding the UNESCO Convention presented in this article are after: Lozano, supra note 26 at pp. 117-150. But see also opposing view, that most of those objections are ill-founded: E. Sarid, International Underwater Cultural Heritage Governance: Past Doubts and Current Challenges, Berkeley J. Int'1 L. vol. 35, 2017, pp. 219-261.

31 CIA, The World Factbook - Colombia, available at: https:/ / www.cia.gov/library/ publications/the-world-factbook/geos/co.html, [last accessed 111. 2019]. 
the coastal states, and the diminishing of any rights coming from the jurisdiction exercised by coastal states.

First, Colombia was preoccupied and disturbed by the UNESCO Convention definition of state vessels which states that: "State vessels and aircraft" means warships, and other vessels or aircraft that were owned or operated by a State and used, at the time of sinking, only for government non-commercial purposes, which are identified as such and which meet the definition of underwater cultural heritage" ${ }^{\prime 2}$. The main concern was that the UNESCO Convention extended the definition, in comparison to the UNCLOS ${ }^{33}$. Such a wide definition, along with other provisions of the UNESCO Convention, may lead to a broader application of state immunity regarding sunken ships, and as Colombian commentators observed, it may lead to the application of immunity without limits of time and space ${ }^{34}$.

The second Colombian concern regarding the UNESCO Convention, and also one of the most prominent one, is that this convention drastically changes the rules established in UNCLOS, and makes a shift from a regime where preservation in situ was coexisting with the possibility of extracting (and applying the law of salvage) towards a regime when strong preference was given just to preservation in situ ${ }^{35}$, severely restraining law of salvage, which may be applicable only as exception in certain situations ${ }^{36}$.

The UNESCO Convention, with its stipulations which clearly restrain the possibility of extracting underwater heritage, was obviously crossing the interests of Colombia regarding the San José galleon (the finding of which was still unconfirmed at the moment when the Convention was being debated). The Colombian government till the end of 2018

32 Article 1.8 of UNESCO Convention.

33 Article 29 of UNESCO Convention.

${ }^{34}$ Lozano, supra note 26 at p. 145.

35 UNESCO Convention, General Principles.

${ }^{36}$ UNESCO Convention, article 4: - Relationship to law of salvage and law of finds. Any activity relating to underwater cultural heritage to which this Convention applies shall not be subject to the law of salvage or law of finds, unless it: (a) is authorized by the competent authorities, and (b) is in full conformity with this Convention, and (c) ensures that any recovery of the underwater cultural heritage achieves its maximum protection. 
was in favour of extracting treasures from the San José galleon, and partially commercializing $\mathrm{it}^{37}$. By accepting the UNESCO Convention in 2001, Colombia would restrain its possibility of following president Santos's plan.

What has to be stressed is that, in general, Colombia was not bluntly against preservation in situ, but rather against restricting options for states only to preservation in situ. Even if preservation in situ seems to be the most adequate form of preservation from the archaeological point of view, many objections are raised. For example, academics pointed out that not in every situation may preservation in situ be practically the best option ${ }^{38}$. Colombia claims that simply, under international law, the law of salvage still exists simultaneously with other obligations, such as preservation in situ $u^{39}$. It cannot be assumed that international law, having developed in such a way, almost totally excludes the law of salvage and law of finds, as enshrined in UNESCO Convention (2001). On the contrary, the Law of Salvage and the Law of Finds as a part of Maritime Law and Admiralty Law are recognized in such countries as the $\mathrm{USA}^{40}$, with an established system of courts to resolve disputes related to maritime law ${ }^{41}$. Also, history knows successful applications of the law of salvage to situations with shipwrecks - as in the case of Nuestra Señora de Atocha ${ }^{42}$.

37 See ABC Cultura, Colombia podrá vender hasta el 80\% del galeón San José, published 1.4.2018) available at: https:/ / www.abc.es/cultura/abci-80-por-ciento-objetos-galeon-sanjose-pueden-someterse-venta-acuerdo-contrato-201804012210_noticia.html [last accessed 111. 2019].

${ }^{38}$ Lozano, supra note 26 at p. 125; See also L. J. Kahn, Sunken treasures: Conflicts between historic preservation law and the maritime law of finds, Tulane Environmental Law Journal, vol. 7(2), 1994, pp. 595-644.

39 See article which discuss in depth if law of salvage and law of finds may be applicable to the case of the galleon San José- M. F. Tedesco, Between the Devil and the Deep Blue Sea: The Shortcomings of Forcing Courts to Choose from the Law of Salvage and the Law of Finds in Treasure Salvage Cases, U.S.F. Maritime Law Journal, vol. 29, 2016.

${ }^{40}$ See Ch.Z. Bordelon, Saving Salvage: Avoiding Misguided Changes to Salvage and Finds Law, San Diego Int'1 L.J., vol. 7, 2005-2006.

${ }^{41}$ See J.A.R. Nafziger, The Evolving Role of Admiralty Courts in Litigation Related to Historic Wreck, Harv. Int'1 L.J., vol. 44, 2003, p. 251 et seq.

${ }^{42}$ R. Kelley, M. May, Admiralty Law: Trial of a Treasure Hunter Treasure Salvors, Inc. v. Nuestra Senora de Atocha, 4 Nova Law Journal, vol. 4, 1980, p. 237 et seq. 
Those issues seem to specially preoccupy Colombia, together with the vagueness of the relation between stipulations of the UNCLOS and UNESCO Conventions. Even if art. 3 of the UNESCO Convention stipulates that its obligations have to be interpreted and applied in a manner consistent with the stipulations of UNCLOS ${ }^{43}$, those two documents are not in conformity regarding the preservation of underwater treasures, as the first (UNCLOS) offers two choices, when the latter clearly indicates that only in situ preservation should be considered. That unclear relationship between those two legal instruments which was raised by Colombia, eventually leads to the non-ratification of UNESCO Convention (2001), as not coherent with widely recognised institutions of law of salvage, and especially with article 303 (3) of UNCLOS 1982.

It has to be noted that not only Colombia, but many other coastal states, especially those with a well-established law of salvage in their legal regimes such as the UK or the USA, decided not to ratify the UNESCO Convention. For example, Greece was also concerned by far reaching restriction of the sovereignty of coastal state ${ }^{44}$ introduced by the UNESCO Convention.

As has already been noted, the case of the San José galleon could have an influence on the development of the international legal obligations of Colombia regarding underwater heritage. Maybe it was the San José galleon in 2001 which sank the ratification of the UNESCO Convention, when the Senate realized in the clear example of an on-going dispute, what legal repercussions the ratification of the UNESCO Convention would have. Wisely for Colombia, its attitude and treaty practice does not pose serious restrictions and leaves the San José galleon mainly in the hands of the national legislature and within the decision of the executive branch in Colombia. It does not mean that Colombia does not and will

${ }^{43}$ UNESCO Convention in Article 3 states: "Nothing in this Convention shall prejudice the rights, jurisdiction and duties of States under international law, including the United Nations Convention on the Law of the Sea. This Convention shall be interpreted and applied in the context of and in a manner consistent with international law, including the United Nations Convention on the Law of the Sea".

${ }^{44}$ See Greece position presented by Anastasia Strati in: A. Strati, Greece, [in:] S. Dromgoole (ed.) The Protection of Underwater Cultural Heritage. National Perspectives in Light of the 2001 UNESCO Convention, Leiden/Boston, 2006, at pp. 118-120. 
not follow the high standard of international law, but in any case, it is not limited only e.g. to in situ protection.

Having presented that international law does not constrain Colombia to follow one and only one established solution, it is therefore indispensable to take a closer look at the legal regime of Colombia applicable to the current dispute.

\section{NATIONAL LAW OF COLOMBiA}

The legal status of the San José galleon, which is most probably sunk within the territorial sea of Colombia ${ }^{45}$, depends on the national legal regime of Colombia. Therefore, it is shaped especially by the national law of Colombia and the judicial decisions of Colombia's courts ${ }^{46}$. Colombian law has different categories to refer to this kind of discoveries, depending on their particular characteristics. The evolution of those concepts can be traced as a legal battle over rights to the San José galleon. This legal battle began with a civil lawsuit filed on January 13, 1989, by Sea Search Armada (SSA), to recognize its rights over shipwreck ${ }^{47}$. Colombia gave permission to search for shipwrecks to a US company (Glocca Morra Company) on $1^{\text {st }}$ March 1982, and those rights were ceded in 1983 by Glocca to Sea Search Armada. When SSA announced the discovery of the shipwreck, according to Colombian law ${ }^{48}, 50 \%$ of the treasure should be given to the finder, leaving $50 \%$ to the State. However, two years later in Colombia the Law 2324 from $1984^{49}$ was passed, which modified the stipulations of the Civil Code ${ }^{50}$ in such a way that SSA was left with

${ }^{45}$ Regarding differences between inter alia Exclusive Economic Zone, Continental Shelf, and High Sea see: R. Frost, Underwater Cultural Heritage Protection, Australian Yearbook of International Law, vol. 25, 2004, pp. 28-36.

${ }^{46}$ Colombian Congress. Political Constitution of Colombia. 1991. Article 230.

47 State Council, Administrative Contentious Chamber. Unification Judgment of February 13, 2018. File 25000-23-15-000-2002-02704-01 (SU). Para. 116

${ }^{48}$ See art. 700 of Colombian Civil Code adopted by Colombian Congress as Law 57 of 1887.

49 Colombian Decree Law 2324 of 1984. Accessible at: https:/ /www.dimar.mil.co/ node/620 [last accessed 20.10.2019].

50 Ibid., art. 188 and 191. 
not $50 \%$ but $5 \%$ of the rights to the treasure. This lawsuit was resolved by the Civil Tenth Judge of the Barranquilla Circuit in 1994, declaring the assets as treasures and allowing SSA to have rights over the assets found ${ }^{51}$. Then, in 1997, the second instance court upheld the 1994 ruling $^{52}$. Besides, the High Courts of the Supreme Court of Justice and the State Council had to rule over this matter, adding an important concept to be treated regarding its legal nature and whether it is cultural heritage $\mathrm{e}^{53}$.

Therefore, as it can be observed, the most relevant legal question, on which the legislation is not clear, and with which the courts were challenged, is the legal nature of the San José galleon, namely, how to classify its treasures and shipwreck itself within the Colombian legal system. The search for the answer to this problem makes visible the evolution of the legal regime of Colombia. In order to respond to that problem, two questions were considered relevant by the Colombian Courts $^{54}$. Within this article, it seems pointless to present a detailed analysis of every step of the evolving Colombian legislation and also every judicial decision. Instead, in this part, a concise analysis of the most relevant problems will be presented.

Before discussing the legal nature of the discovery under Colombian law, some courts decided that it was necessary also to respond to a first, preliminary question - namely if Colombia in general has the right to underwater treasures such as the San José galleon ${ }^{55}$.

Whatever legal rights there could be to the property on Colombian soil before 1821, such as, for example, those derived from Pope Alexander the Sixth's Bull "Inter Caetera" 56 , the crown argument is that at the beginning of the XIX century, during the so-called Wars of Independence ${ }^{57}$ in

51 Judgment of State Council, supra note 47. par. 117.

52 Ibid., par. 121.

53 See Supreme Court of Justice, Civil Cassation Chamber. Judgment of July 5, 2007, File 08001-3103-010-1989-09134-01 and Judgment of State Council, supra note 47.

${ }^{54}$ Judgment of State Council, supra note 47, para. 193.

55 Ibid., para. 193.

56 See H. Vander Linden, Alexander VI. and the Demarcation of the Maritime and Colonial Domains of Spain and Portugal, 1493-1494, The American Historical Review, Vol. 22, no. 1, October 1916, pp. 1-20.

57 "Between 1808 and 1826 all of Latin America except the Spanish colonies of Cuba and Puerto Rico slipped out of the hands of the Iberian powers who had ruled the 
Latin America, and also when the San José galleon was sunk, Spain was defeated and the General Congress of Colombia issued the Law of October 16, 1821, which was intended to confiscate the assets of the enemy government ${ }^{58}$, a precept reiterated in article 2 of the 1830 Constitution $^{59}$. Moreover, with Law 12 of $1881^{60}$, which approved the Treaty of Peace and Friendship between Colombia and Spain, in Article 1 of this treaty the two States explicitly agreed that any past claims would be forgotten. This analysis allowed the Colombian Courts to reach the conclusion that any discussion about the ownership of assets related to the results of the independence struggle and decolonization was settled, in accordance with the normative sources mentioned above ${ }^{61}$.

In summary, even if the assets found were primarily Spanish property, after the War of Independence with the subsequent laws, Colombia claimed the Spanish assets as its own, without opposition from Spain, leaving no possibility that Spain can make a legal claim based on reasonable grounds.

Even if the first question does not have enormous gravity, the second is much more relevant and contemporary for the current dispute. The clue to the problem seems to be how to classify the San José galleon under the national law of Colombia. Should it be treated e.g. as a treasure or as underwater cultural heritage and, of course, with all the repercussions of such classification? The response to that question may be found in the Colombian legislature, but more importantly, in the decisions of courts related to the San José galleon case. Therefore, the applicable national law and also judicial decisions that will be mentioned, are not presented in

region since the conquest", at: https:// www.britannica.com/place/Latin-America/Theindependence-of-Latin-America [last accessed 17.10.2019].

58 General Congress of Colombia, Law October 16, 1821. On the confiscation of property belonging to the enemy government and those fleeing from the Republican, Article 1 and 2.

59 Colombian Congress, Constitution of 5 May 1830, Article 2: “The Colombian Nation is irrevocably free and independent of any foreign power or domination, and is not and will never be the patrimony of any family or person".

${ }^{60}$ Official journals numbers 4976 of March 26, 1881, 4998 of April 19, 1881 and 5236 of January 4, 1882. National Coding, Volume XXXI number 4073.

${ }^{61}$ Judgment of State Council, supra note 47, para. 193. 
exact chronological order, but rather by use of the main concepts related, namely: treasure, sea salvage, abandoned property, and underwater cultural heritage.

\section{TREASURE}

The civil law concept of treasure is common for many legal systems ${ }^{62}$. Also, it is known in the Colombian civil law, and has been regulated since 1887 by article 700 of the Colombian Civil Code.

This figure points out two important aspects. First, treasure is understood as precious property without an owner, which has been hidden. And, second, that the person who discovers a treasure will be the proprietor of $50 \%$ of the ownership of those assets, if they are found in a remote place, as stated in article 701 of the same Code ${ }^{63}$.

Since 1994 courts have been confronted with the legal question, how not only to classify the San José galleon itself, but more specifically, how to treat those (supposedly) unimaginable riches in gems and coins, (which in the argument of SSA, could be commercialized). At first, the Civil Tenth Judge of the Circuit of Barranquilla and the Superior Court of Barranquilla, Civil and Family Decision Chamber, treated the assets with a classical vision, whose narrative takes us back to the times when sailors needed to hide their assets, either by burying them or hiding them in strategic places, to prevent them from being captured by invaders ${ }^{64}$. The ancient situation that allowed that, should a person find a treasure, they would obtain the property of those goods ${ }^{65}$. However, the current legislation, grants only $50 \%$ of the finding to the discoverer.

In relation to the case of the San José galleon, on March 7, 1997, the Superior Tribunal of Barranquilla concluded in its ruling that those lost precious objects can be classified as treasure under the civil law, and

${ }^{62}$ Civil Code of France, Art 716.; Louisiana Civil Code art. 3423 (1870); Civil Code of the Republic Uzbekistan, Art. 196.

63 Article 701 of Colombian Civil Code.

${ }^{64}$ Judgment of State Council, supra note 47, para. 193.

65 A.B. Guzmán, Derecho Privado Romano. Vol. I. Legal Editorial Jurídica de Chile, 1996. 1st edition, p. 540-549. 
therefore the finder may be entitled to $50 \%$ of them, under the figure of occupation $^{66}$, regulated in the Colombian Civil Law ${ }^{67}$.

Nevertheless, later on, also in relation to the case of the San José galleon, an interpretation by the Office of Consultation and Civil Service of the Colombia State Council was issued ${ }^{68}$. It was stated that it is essential that the goods must be buried in the ground or hidden in movable property to be considered as treasure. Because of that reason, the goods within the vessel/shipwreck found cannot be classified as a treasure.

\section{Sea Salvage}

Also, there was an attempt in the Judgment of the State Council to treat the riches of the San José galleon as Sea Salvage ("Especie náufraga" in Spanish) ${ }^{69}$. I us naufragium or sea salvage is a common figure in various civil $\operatorname{codes}^{70}$, and can be also found in the Colombian Civil Code in article $710^{71}$. This article is applicable to those goods which are saved from the wreck of a ship and, as the owner is unknown, they are declared as abandoned property. Nevertheless, in its interpretation of 2018, the State Council $^{72}$ explained that this category may not be applicable to findings like lost shipwrecks which were lost for a long period of time and have been recently discovered.

${ }^{66}$ Judgment of State Council, supra note 47, para. 125.

${ }^{67}$ See Colombian Civil Code, article 685.

${ }^{68}$ State Council Consultation and Civil Service Room. Concept of December 10, 1981, Rad. 1610.

${ }^{69}$ Judgment of State Council, supra note 47, para. 194 and following. See in general: T. Y. Ortega Gonzalez, ALGUNAS CONSIDERACIONES SOBRE EL NAUFRAGIUM Y SALVAMENTO MARÍTIMO: DE ROMA AL DERECHO MODERNO, Universidad de Las Palmas de Gran Canaria 2015, accesible at: https://accedacris.ulpgc.es/bitstr eam/10553/17968/4/0726176_00000_0000.pdf) [last accessed 1.11.2019].

${ }^{70}$ UK - Merchant Shipping Act 1995. Part IX, Chapter, available at: http://www. legislation.gov.uk/ukpga/1995/21/part/IX/chapter/1. See also: Spain - Law 14/2014, de 24 de julio, de Navegación Marítima, Chapter IV, available at: https:/ / www.boe.es/ buscar/act.php?id=BOE-A-2014-7877\&p=20150526\&tn=0 [last accessed 1.11.2019].

${ }^{71}$ Colombian Civil Code, Article 710.

72 Judgment of State Council, supra note 47, para. 193. 


\section{ABANDONED PROPERTY}

It will also be just briefly mentioned that the institution of abandoned property, as applicable to the current dispute, was considered by the High Courts of Colombia as well ${ }^{73}$.

\section{UNDERWATER CULTURAL HERITAGE}

All previously mentioned possible classifications of the San José galleon and its treasures are applicable to goods which have no importance beyond the purely commercial, without relevance to the Nation, or are not a specially protected category of goods which may be classified as historical or cultural heritage.

In that long-lasting debate, in 2007, the Supreme Court of Justice in its Judgment ${ }^{74}$, made a landmark decision, to basically end all of those previous disputes ${ }^{75}$ and declare that none of those previously mentioned categories may be applicable in the current dispute. It did so by invoking as applicable to the San José galleon a law from $1959^{76}$, which states that cultural objects which have the status of national heritage should be protected and preserved by Colombian Authority ${ }^{77}$.

Article 1 of the Law 163 of 1959 stipulates that the specially protected category should have the nature of "natural historical and artistic heritage", movable monuments and other objects that are of interest and are

${ }^{73}$ Ibid., para. 193.

${ }^{74}$ Supreme Court of Justice, Civil Cassation Chamber, Judgment of July 5, 2007, File 08001-3103-010-1989-09134-01.

75 Of course, the reference about ending is made in relation to the dispute how to classify the galleon San José with its treasures, which is under discussion in this part. The dispute still was relevant for other issues, such as right to compensation for private investor.

${ }^{76}$ Congress of the Republic of Colombia, Law 163 of 1959.

77 This reasoning was followed in 2008 by the State Council, see: State Council, Administrative Contentious Chamber, Unification Judgment of February 13, 2018. File 25000-23-15-000-2002-02704-01 (SU), Paragraph 193. 
on the surface or under the national ground ${ }^{78}$. Furthermore, in the same law, it is clarified that the aforementioned goods cannot have the quality of treasure according to article 700 of the Colombian Civil Code ${ }^{79}$. This article from 1959, was interpreted by the Court in the light of the Colombian Political Constitution of the 1991, which states the protections of the cultural heritage by the Colombian State, and remarks on the inalienable, non-attachable, and imprescriptible as characteristics of these important goods ${ }^{80}$. Also, law 197 of 1997 reinforces that protection, stating that the goods of the colonial, independence, and similar ages, which would have been declared national goods, will be of cultural interest, belonging to the National Cultural Heritage ${ }^{81}$.

From that moment on, under Colombian law, the San José galleon should be treated as potential underwater cultural heritage. Potential, because according to Colombian law, there is only one entity entitled to declare the status of cultural heritage - the National Council of Cultural Heritage ${ }^{82}$. Such understanding has been recently confirmed by the Constitutional Court in its Judgment C-264 de $2014^{83}$. Such an interpretation was also followed by the State Council, who stated that:

"The collective rights and interests related to cultural, historical, archaeological, or submerged cultural heritage, have a reinforced judicial protection, because in the light of articles 63 and 72 of the Political Constitution, they are assets that are under the protection of the State, they belong to the Nation, and, therefore, they are inalienable, non-attachable and imprescriptible." ${ }^{14}$

So, right now, under the Colombian system, it is up to the National Council of Cultural Heritage, to decide whether findings such as the San

${ }^{78}$ Congress of the Republic of Colombia, Law 163 of 1959, Article 1.

79 Ibid., Article 14.

${ }^{80}$ Colombian Congress. Political Constitution, 1991, Article 72.

${ }^{81}$ See article 4 of the Law 397 of 1997, available at: http:/ / www.secretariasenado. gov.co/senado/basedoc/ley_0397_1997.html. See also Supreme Court of Justice, Civil Cassation Chamber, Judgment of July 5, 2007, File 08001-3103-010-1989-09134-01.

${ }^{82}$ Congress of the Republic of Colombia, Law 1675 of 2013.

${ }^{83}$ Constitutional Court, Judgment C-264 of 2014, Judge Alberto Rojas Ríos, 29 April 2014.

${ }^{84}$ Judgment of State Council, supra note 47. Decision I.2. 
José galleon are Underwater Cultural Heritage. And it is not precisely known when it will happen, as many scientific inquiries has to be conducted, which is a time-consuming process.

All of that judicial evolution from treasure to underwater cultural heritage was thanks to the litigation of SSA. At the end of the day, regarding the rights of US private company SSA, it can be concluded, that during that long litigation the company confirmed its rights, but not to the treasure itself from the galleon, but as was reaffirmed by Constitutional Court's Judgments, to compensation which should be equivalent to the specified percentage of the value. SSA has no right to the treasure itself, as any treasures from the galleon San José are most probably cultural heritage ${ }^{85}$. The most recent and burdensome development is that authorities have confirmed that the location is different from that provided by SSA ${ }^{86}$, probably leaving the SSA with no rights in the matter at all.

\section{Politics AND Diplomacy}

After describing the first two elements, it may be observed that international law does not provide a definite answer or a unique solution. But after long evolution and various Judgments in the legal system of Colombia since 2007, the legal status of the San José galleon under the national law of Colombia may be recognized as a specially protected category. However, such a legal situation leaves still plenty of space for the last two elements, which will be discussed in this section, namely, politics and diplomacy. Until November 2015, all of the legal battles surrounding the San José galleon, under the national law of Colombia, were based on the assumption that the private company had made an

${ }^{85}$ See Judgment of Constitutional Court, case C-474 of 2003. See also the Judgment of Colombian Constitutional Court C-668/2005.

${ }^{86}$ See Notice of the Vice President from 9.10.2019, available at: https://mlr. vicepresidencia.gov.co/Paginas/prensa/2019/Declarar-al-Galeon-San-Jose-patrimoniocultural-en-su-integridad-pedira-Gobierno-al-Consejo-Nacional-de-Patrimonio-Cultural. aspx [last accessed 1.11.2019]. 
accurate discovery in 1982, but it was still not ascertained that the San José galleon was truly found.

On 27 November 2015, the galleon was found by personnel of the Colombian Institute of the Anthropology and History (ICANH), the naval forces of Colombia, and by the Maritime General Office (DIMAR), as the President of the Republic of Colombia, Juan Manuel Santos announced on December $2015^{87}$. After that, the debate surrounding the galleon San José has moved from speculations to a higher level - politics and diplomacy. The president of Colombia had a clear vision of the solution and his government was pushing for the option that the Colombian state would enter an agreement with a private investor, who would invest money in underwater operations. What is more, the private party would be responsible for the creation and administration of the museum in Cartagena, when the remains of the San José galleon would be displayed. By such a construction, President Santos proudly announced that Colombian citizens would not pay a penny for that operation, as all of the costs would be assumed by the private party ${ }^{88}$. From the beginning, the President was firmly claiming that whatever solution would be adopted, it was only up to Colombia, not e.g. the international community, to make decisions regarding the San José galleon ${ }^{89}$.

Such a proposal raised some serious doubts in Colombian society for various reasons. First, academics especially were arguing that the Colombian government was not free to decide about the San José galleon and its treasure as they wanted, because that treasure formed a part of underwater cultural heritage, and belonged to the Nation ${ }^{90}$. Even the

${ }^{87}$ See: http:/ / es.presidencia.gov.co/sitios/busqueda/noticia/160730-El-Galeon-SanJose-lo-vamos-a-recuperar-afirmo-el-Presidente-Santos/Noticia, [last accessed 1.11.2019].

${ }^{88}$ See: http:/ / es.presidencia.gov.co/discursos/180723-Declaracion-del-PresidenteJuan-Manuel-Santos-sobre-el-Galeon-San-Jose, [last accessed 1.11.2019].

89 See: Santos: "San José is in Colombian waters and, therefore, it is Colombian", Diplomat in Spain, 15.05.2018, available: https:/ / thediplomatinspain.com/en/2018/05/ santos-san-jose-is-in-colombian-waters-and-therefore-it-is-colombian/ [last accessed 1.11.2019].

90 See: https://www.elespectador.com/noticias/actualidad/universidad-nacionalpide-que-naufragio-del-galeon-san-jose-no-sea-intervenido-articulo-749634. See also: https:/ / www.bluradio.com/nacion/comite-consultivo-de-la-unesco-critica-explotacioncomercial-del-galeon-san-jose-177693-ie3509872e, [last accessed 1.11.2019]. 
National Attorney Office issued a negative opinion regarding the plan of president Santos ${ }^{91}$.

The discovery of the San José galleon also attracts the attention of the international community and various states. Needless to say, they were generally very critical of the idea of president Santos.

The main diplomatic dispute regarding the San José galleon is between Colombia and Spain. Colombia has highlighted that is not bound by any international legal instrument and is, therefore, not obliged to take into account the interest of Spain. Spain, acknowledging the lack of applicable legal conventions, still may have some legal arguments regarding its rights over the San José galleon ${ }^{92}$. A Spanish jurist and ambassador clearly stated that: "in case of San José, there is not the slightest of doubts that the San José is a property of the Spanish State" ${ }^{\prime \prime 3}$.

There is no space for profound analysis of those arguments, however, here they will be briefly mentioned. Many authors argue that some general principles incorporated into UNCLOS are nowadays binding as part of international customary law. The obligation of international cooperation to protect the underwater cultural heritage and the maintenance of the immunity of the sunk state ships, even if they are found within internal waters or territorial sea of another state ${ }^{94}$ are mentioned as examples of those rules from UNCLOS which are of a customary character. Also, some argue that of a customary character is the rule also, included in the

91 See: Opinion of Procuradoria Nacional de Nacion. Available at: https:/ / es.scribd. com/document/433394642/VEEDURIA-Refuta-a-La-Ex-Ministra-de-Cultura-MarianaGarces-Cordoba\#from_embed, [last accessed 1.11.2019].

92 See: http://www.exteriores.gob.es/Portal/es/SalaDePrensa/Comunicados/ Paginas/2019_COMUNICADOS/20191010_COMU149.aspx. See also: https://elpais. com/cultura/2019/10/17/actualidad/1571310899_047405.html. [last accessed 3.11.2019].

93 J.A. de Yturriaga Barberán, Hallazgo del galeón 'San José': los últimos de Cartagena, Argentina - Facultad de Derecho de la Universidad Nacional de Córdoba - Núm. VII-1, Junio 2016, p. 30.

${ }^{94}$ See in general C. Parra, Protection of Underwater Cultural Heritage from the International Law Perspective, [in:] P.A. Fernández (ed.), New approaches to the law of the sea: In honor of ambassador José Antonio de Yturriaga-Barberán, New York: Nova Science Publisher 2017; M. Aznar, Treasure Hunters, Sunken State Vessels and the 2001 UNESCO Convention on the Protection of Underwater Cultural Heritage, International Journal of Marine and Coastal Law, vol. 25, 2010, p. 231. 
UNESCO Convention ${ }^{95}$, according to which States Parties shall ensure that proper respect is given to all human remains located in maritime waters ${ }^{96}$ and to treat those sites as graveyards ${ }^{97}$.

The Spanish argument of the immunity of a state vessel, applicable to the galleon San José which was most probably encountered on Colombian territory, would be quite difficult to sustain and enforce, in the case of a legal dispute between Spain and Colombia, as it is not based on a firm and clear legal international obligation of Colombia, but rather on the argument that some rules have become of customary character and, therefore, should be applicable, even to underwater shipwrecks within the territory of States.

Spain is definitely not the only State, however, with a legal interest in the current dispute. However, the legal demands of other States, such as Spain, reasonable or not, lack a forum where Spain could present its legal dispute against Colombia, as Colombia no longer accepts the compulsory jurisdiction of the ICJ, and is not a party to UNCLOS. Even if Colombia is not bound by international conventions, also some academics argue that under international law a rule of obligation of cooperation of interested States to resolve disputes regarding underwater cultural heritage has been developed $^{98}$. Therefore, even if non-contracting States are not formally forced to do so, when finding a solution to protect underwater cultural heritage, cooperation between interested states seems to be the best option $^{99}$.

Many organizations have expressed their concern in various forms, as for example UNESCO called for Colombia to refrain from commercial exploitation of the San José100.

95 See article 2, point 9 and norm 5 from Annex to UNESCO Convention.

96 See Aznar, supra note 94 at p. 219.

97 E. Pérez Álvaro, Shipwrecks as Watery Graves: Cultural Attitudes, Legal Approaches and Ethical Implications, [in:] J.M. Sánchez Patrón et al. (eds.), Derecho del mar y sostenibilidad ambiental en el Mediterráneo, Editorial Tirant lo Blanch 2014, p. 134 and 141.

98 Ibid., at p. 136. See also Aznar, supra note 94.

99 Yturriaga Barberán, supra note 93 at p.18.

100 See a letter to Colombian Minister of Culture, Carta de la Unesco del 20 de abril del 2018, https://www.wradio.com.co/noticias/actualidad/unesco-desmiente-a-proponentedel-galeon-san-jose/20180424/nota/3741414.aspx. See also: https:/ / www.abc.es/cultura/ 
A change in government policy occurred after the election of president Duque in 2018. At the national level, the new president after the elections found himself in a situation in which the process to find a private company to cooperate with the government had already been announced ${ }^{101}$. The Ministry of Culture, which is responsible for the protection of the cultural heritage, issued a resolution of provisional suspension of the APP selection process for the first time on 23 July 2018 ${ }^{102}$, then extending it at various times until today ${ }^{103}$. Also the government recently confirmed its dedication to declaring the San José galleon as cultural heritage ${ }^{104}$.

At the international level, also international organizations, such as ICOMOS, took an active part in the dispute, as e.g. ICOMOS offers its expertise to the Colombian heritage authorities ${ }^{105}$. Regarding Spain, after 2018 the cooperation seems to have been working well, and diplomats from both countries have found common ground. In December 2018 it was announced that both States would work together ${ }^{106}$. Most recently, as announced on $18^{\text {th }}$ October 2019, both States have agreed that commercial

abci-unesco-denuncia-explotacion-comercial-galeon-san-jose-201804242154_noticia.html [last accessed 17.11.2019].

101 See: Acuerdo de la inciativa 23 de marzo del 2018, https:/ / www.contratos.gov. co/consultas/detalleProceso.do?numConstancia=18-20-5038 [last accessed 8.11.2019].

102 See: Resolución de suspensión del 23 de julio del 2018. https:/ / www.contratos. gov.co/consultas/detalleProceso.do?numConstancia=18-20-5038 [last accessed 9.11.2019].

103 See: Resolución No 465 de 2019 por medio de la cual se prorroga la suspensión del proceso de selección del 6 de marzo del 2019, https: / / www.contratos.gov.co/consultas / detalleProceso.do?numConstancia=18-20-5038, see also https:/ / thecitypaperbogota.com/ news/colombia-extends-suspension-of-partnership-to-salvage-san-jose-galleon/22320 [last accessed 9.11.2019].

104 See: Notice of the Vice President from 9.11.2019: https://mlr.vicepresidencia. gov.co/Paginas/prensa/2019/Declarar-al-Galeon-San-Jose-patrimonio-cultural-ensu-integridad-pedira-Gobierno-al-Consejo-Nacional-de-Patrimonio-Cultural.aspx [last accessed 15.11.2019].

105 See: https:/ / www.icomos.org/en/77-articles-en-francais/42628-le-san-jose-ungalion-espagnol-perdu-dans-les-eaux-colombiennes-en-1708-1-icomos-offre-son-expertiseaux-autorites-du-patrimoine-colombien-3 [last accessed 20.11.2019].

106 See: Colombia and Spain agree to manage together wreck of the galleon San José. Borrell announces a preliminary agreement which excludes involvement of any private company, December 13, 2018, available at https:/ / thediplomatinspain.com/en/2018/12/colombiaand-spain-agree-to-manage-together-wreck-of-galleon-san-jose/ [last accessed 20.11.2019]. 
extraction of the treasures of the San José galleon is no longer a viable option $^{107}$.

\section{CONCLUSIONS}

As highlighted from the beginning, the case discussed is an on-going problem, and even if the dispute has been going on since 1980's, many pivotal changes have occurred in the meantime. For instance, after the SSA-prolonged-courts battle, which also witnessed many surprising decisions, today the US company may have no rights at all if the location of the shipwreck was inaccurate. However, in the current dispute, even such a firm fact as the location of the galleon itself may still be questioned. Right now, as for end of 2019, the landscape after the battle is that the national law (most probably) protects the San José galleon as cultural heritage - the result which was reached after almost 40 years of legal battle. On the international plane, even if at the beginning Colombia was forcing a solution which put her on a collision course with many international actors, after 2018 Colombia is working, hand in hand with Spain, is searching for a satisfactory result.

We will see if it is the end of the bumpy road, or just a quiet moment before next surprising revelations and a new turn in that story.

107 Official press release of Ministry of Foreign Affairs regarding the galleon San José, nr 157 from 18 October 2019 available at: https:/ / es.scribd.com/document/430954116/ Comunicado-sobre-el-Galeon-San-Jose-18-oct-2019\#from_embed. [last accessed 22.11.2019]. 